\title{
THE EFFECT OF VIRAL MARKETING ON BLACKBERRY MESSENGER APPLICATIONS ON CUSTOMER SATISFACTION THROUGH PURCHASING DECISIONS ON UNIVERSITY STUDENTS IN SIDOARJO
}

\author{
Mochamad Rizal Yulianto ${ }^{1}$, Suhartono ${ }^{2}$, Ronny ${ }^{3}$ \\ STIE Perbanas Surabaya \\ Jl. Nginden Semolo 34-36 Surabaya
}

\begin{abstract}
Abstrak
Tujuan penelitian ini adalah menguji pengaruh viral marketing pada aplikasi Blackberry Messenger terhadap kepuasan pelanggan melalui keputusan pembelian pada mahasiswa perguruan tinggi di Sidoarjo. Hipotesis penelitian ini menyatakan bahwa viral marketing berpengaruh terhadap kepuasan pelanggan melalui keputusan pembelian. Data penelitian ini dikumpulkan dengan kuisioner yang dibagikan kepada 180 responden di beberapa perguruan tinggi yang ada di Sidoarjo. Dari data yang diperoleh kemudian dilakukan uji validitas, uji reliabilitas dan analisis structure equation model dengan menggunakan aplikasi statistik SmartPLS. Hasil penelitian ini menunjukkan bahwa viral marketing pada aplikasi Blackberry Messenger berpengaruh positif signifikan terhadap kepuasan pelanggan melalui keputusan pembelian pada mahasiswa perguruan tinggi di Sidoarjo.
\end{abstract}

Kata kunci : viral marketing, kepuasan pelanggan, keputusan pembelian

\section{Abstract}

The purpose of this study is to examine the effect of viral marketing on Blackberry Messenger applications on customer satisfaction through purchasing decisions on university students in Sidoarjo. This research hypothesis states that viral marketing affect customer satisfaction through purchasing decisions. This research data was collected by questionnaires distributed to 180 respondents in several universities in Sidoarjo. From the data obtained then tested the validity test, reliability test and structure equation model analysis using the SmartPLS statistical application. The results of this study indicate that viral marketing on the Blackberry Messenger application have a significant positive effect on customer satisfaction through purchasing decisions on university students in Sidoarjo.

Keywords : viral marketing, customer satisfaction, purchasing decisions 


\section{Pendahuluan}

Perkembangan bisnis saat ini dipengaruhi oleh berbagai faktor mengikuti perkembangan yang terjadi di lingkungan sekitarnya. Persaingan bisnis yang ketat menuntut para produsen untuk berpikir ekstra dalam menjalankan bisnis yang mulai dipengaruhi globalisasi dan salah satu yang paling besar pengaruhnya dalam bisnis dan pemasaran adalah kecanggihan yang mempermudah kinerja teknologi dan banyaknya pengguna teknologi di kalangan produsen dan konsumen. Survei yang dilakukan oleh www.internetworldstats.com mengenai pengguna internet se-dunia di tahun 2017 menempatkan Indonesia di peringkat lima setelah Brazil. Peringkat pertama diisi oleh China, selanjutnya oleh India, dan ketiga oleh Amerika Serikat. Hal ini menunjukkan bahwa pengguna internet aktif di Indonesia berjumlah sangat banyak bila dibandingkan dengan pengguna internet lain di beberapa negara lainnya yakni mencapai 132,7 juta pengguna.

Aplikasi chatting adalah metode komunikasi utama pengguna handphone. 90\% konsumen mengaku menggunakannya tiap hari dan 60\% menggunakannya berkali - kali dalam sehari. Jumlah rata - rata aplikasi chatting yang dimiliki oleh pengguna handphone di Indonesia adalah 4,2 aplikasi, dengan BlackBerry Messenger ( $B B M)$, WhatsApp, dan Line menjadi tiga aplikasi yang paling banyak digunakan (Paragian, 2016). Salah satu riset Kantar TNS di bulan Desember 2016 yang menyatakan bahwa BBM adalah pemimpin brand awareness dalam pasar aplikasi pesan instan di Indonesia, di atas WhatsApp dan Line. Pencapaian $B B M$ dapat dipahami karena BBM telah merasuk dalam kegiatan sehari-hari masyarakat Indonesia, baik dari kalangan profesional, ibu rumah tangga, hingga pada generasi milenial (Priyandana, 2017).

Meski aplikasi pesan instan telah menjamur, namun masyarakat Indonesia masih tetap setia menggunakan $B B M$ dalam berkomunikasi sehar-hari. SimilarWeb menyatakan, 87,5\% pengguna Android di Indonesia menginstal $B B M$ ( Haryanto, 2017). Banyaknya pemasar yang menggunakan berbagai aplikasi chatting seperti BBM untuk melakukan promosi mampu menarik perhatian dari konsumen agar konsumen melakukan kegiatan pembelian mengenai produk yang dipasarkan. Adanya kegiatan berbelanja dengan sistem online shopping, dapat 
membantu para pemasar dalam memasarkan produknya dan juga para konsumen semakin mudah dalam melakukan pembelian. Karena konsumen merasa berbelanja secara online lebih nyaman, praktis dan tidak memerlukan biaya yang besar. Banyaknya konsumen yang menggunakan aplikasi $B B M$ dijadikan peluang oleh para pemasar untuk meningkatkan penjualan pada bisnis mereka.

Dengan adanya aplikasi fitur broadcast message maka $B B M$ menjadi media penjualan memudahkan komunikasi antara pemasar dan konsumen. Dengan begitu, informasi yang disampaikan dapat diterima oleh banyak orang . Komunikasi pemasaran yang demikian dikenal dengan Viral Marketing. Viral marketing dapat berupa pemasaran dari mulut ke mulut (WOM) yang diperkuat dengan aktivitas pemasaran dan efek dari jaringan sosial (Kotler dan Keller, 2009 ). Dari hal sekecil ini dapat dijadikan suatu bahan pertimbangan bagi para pengguna $B B M$ dalam mengambil sebuah keputusan untuk bertransaksi atau tidaknya dengan para pemasar. Beberapa calon pembeli cenderung memutuskan untuk membeli produk barang yang menarik menurut dirinya baik dari segi harga, rupa atau gambar meskipun produk tersebut kurang dibutuhkan.

Hasil survei Asosiasi Penyelenggara Jasa Internet Indonesia (2016) menghasilkan bahwa pengguna internet didominasi oleh kalangan usia 16-20 tahun sejumlah 75,5\%, dan di kalangan usia 21 - 25 tahun sejumlah 75,8\%. Pada umumnya, usia tersebut adalah fase dimana seseorang menjadi pelajar dan mahasiswa. Di Sidoarjo sendiri jumlah populasi mahasiswa selalu bertambah setiap tahunnya. Hal ini bisa dirasakan dengan semakin bertambahnya jumlah Perguruan Tinggi yang berdiri di Sidoarjo. Meskipun belum terdapat kampus negeri di wilayah Sidoarjo, namun telah ada 11 (sebelas) kampus swasta dalam naungan LLDIKTI Wilayah VII yang telah berdiri di Sidoarjo sampai dengan tahun 2018.

Dengan seringnya intensitas mahasiswa, baik penggunaan dengan tujuan chating ataupun sekedar membuat sebuah status dan juga memposting sebuah gambar atau photo melalui BBM maka hal tersebut mampu dimanfaatkan oleh pemasar untuk mempromosikan produk barang ataupun jasanya melalui program Broadcast Message dalam aplikasi BBM. Para mahasiswa tersebut akan secara sengaja maupun tidak sengaja membaca pesan yang telah dikirimkan oleh 
pemasar melalui program tersebut. Pemasar harus secara optimal memanfaatkan layanan ini dengan memaksimalkan promosinya baik dari segi bahasa maupun gambar yang mampu mencuri perhatian agar pengguna merasa tertarik dan membaca isi pesan tersebut. Kondisi mahasiswa yang telah mempunyai penghasilan sendiri, baik itu penghasilan tetap maupun tidak tetap pun dapat mempengaruhi daya beli mereka sehingga secara tidak langsung juga mempengaruhi mereka dalam melakukan keputusan pembelian pada suatu produk yang ditawarkan melalui media sosial khususnya $B B M$.

Mahasiswa cenderung gemar bersosialita dengan seringkali menunjukkan jati diri mereka melalui sosial media dengan cara membentuk suatu group $B B M$ bersama dengan teman atau rekan mereka yang mempunyai karakteristik yang sama misalnya pekerjaan, tempat tinggal atau hobby. Dengan melakukan hal tersebut mereka cenderung merasa puas dan bangga bila pengalaman yang mereka dapatkan dapat dibagikan dan diketahui oleh orang lain.

Dengan adanya latar belakang masalah seperti demikian, penulis ingin mengetahui apakah ada pengaruh viral marketing pada aplikasi BlackBerry Messenger terhadap kepuasan pelanggan melalui keputusan pembelian pada mahasiswa di Sidoarjo.

\section{Viral Marketing}

Viral marketing merupakan suatu teknik pemasaran dengan memanfaatkan media elektronik untuk mencapai suatu tujuan pemasaran tertentu yang dilakukan melalui proses komunikasi yang secara berantai dan memperbanyak diri. Konsep kerjanya yang mirip dengan perkembang biakann virus, yaitu memperbanyak diri sendiri, membuat konsep ini disebut viral marketing (Kotler dan Keller, 2009 ). Viral marketing berusaha membuat seseorang secara sukarela menyampaikan pesan pemasaran ke sesamanya. Viral marketing, word of mouth marketing, buzz marketing atau apapun istilahnya, mungkin merupakan salah satu pemasaran yang paling efektif. Dalam viral marketing pelanggan yang merasa puas melakukan upaya pemasaran. Sebagai akibatnya, upaya dan biaya pemasaran yang dikeluarkan oleh perusahaan menjadi minimal.

\section{Kepuasan Pelanggan}

Phillip Kotler (2015: 70 ) menyatakan bahwa kepuasan pelanggan adalah 
perasaan senang atau kecewa seseorang yang muncul setelah membandingkan antara kinerja produk yang dipikirkan terhadap kinerja yang diharapkan. Jika kinerja produk tersebut berada di bawah harapan, maka pelanggan tidak puas. Jika kinerja produk tersebut memenuhi harapan, maka pelanggan akan puas. Jika kinerja melebihi harapan, maka pelanggan sangat puas atau senang.

\section{Keputusan Pembelian}

Pengambilan keputusan merupakan kegiatan individu yang secara langsung terlibat dalam mendapatkan dan mempergunakan barang yang ditawarkan. Keputusan pembelian dipengaruhi oleh faktor sosial, yaitu dalam kelompok referensi, dimana kelompok referensi seseorang terdiri dari seluruh kelompok yang mempunyai pengaruh langsung (Andini, 2014). Andini juga menyebutkan bahwa kegiatan pembelian merupakan rangkaian tindakan fisik maupun mental yang dialami seorang konsumen dalam melakukan pembelian. Keputusan pembelian menjadi suatu proses pengintegrasian yang mengkombinasi sikap pengetahuan untuk mengevaluasi dua atau lebih perilaku alternatif, dan memilih salah satu diantaranya.

\section{Metode Penelitian}

Jenis penelitian yang digunakan adalah penelitian kuantitatif. Populasi yang digunakan dalam penelitian ini adalah mahasiswa perguruan tinggi di Sidoarjo dan sampel yang digunakan sejumlah 180 responden. Teknik pengambilan sampel yang digunakan untuk memperoleh responden dalam penelitian ini adalah salah satu cara dari purposive sampling yaitu judgement sampling. Kriteria respoden dalam penelitian ini adalah mahasiswa perguruan tinggi di Sidoarjo yang pernah melakukan transaksi melalui aplikasi BlackBerry Messenger, sehingga diperoleh variabilitas data dalam menggambarkan pengaruh Viral Marketing, Kepuasan Pelanggan dan Keputusan Pembelian. Dari data yang diperoleh kemudian dilakukan uji validitas, uji reliabilitas dan analisis structure equation model dengan menggunakan aplikasi statistik SmartPLS.

\section{Deskripsi Responden}

Berdasarkan hasil pengumpulan data yang telah dilakukan maka diperoleh 
data mengenai identitas responden untuk melengkapi informasi penelitian. Data kuisioner dibagikan pada empat perguruan tinggi di Sidoarjo. Adapun data responden yang diidentifikasikan adalah berdasarkan jenis kelamin dan usia seperti pada Tabel 1 berikut.

Tabel 1

Profil Responden

\begin{tabular}{llcr}
\hline Profil Responden & \multicolumn{1}{c}{ Kategori } & Frekuensi & Presentase \\
\hline Jenis Kelamin & Pria & 78 & 43.3 \\
& Wanita & 102 & 56.7 \\
& Total & $\mathbf{1 8 0}$ & $\mathbf{1 0 0 . 0}$ \\
Usia & 20 tahun & 54 & 30.0 \\
& 21-25 tahun & 81 & 45.0 \\
& 26-30 tahun & 36 & 20.0 \\
& $>$ 31 tahun & 9 & 5.0 \\
& Total & $\mathbf{1 8 0}$ & $\mathbf{1 0 0 . 0}$ \\
& Univ. Muhammadiyah Sidoarjo & 74 & 41.1 \\
& Univ. Nahdlatul Ulama Sidoarjo & 48 & 26.7 \\
& STKIP PGRI Sidoarjo & 32 & 17.8 \\
& Akper Kerta Cendekia & 26 & 14.4 \\
& Total & $\mathbf{1 8 0}$ & $\mathbf{1 0 0 . 0}$
\end{tabular}

Sumber: Data diolah

Berdasarkan jenis kelamin, responden didominasi oleh mahasiswa yang berjenis kelamin wanita yaitu sebanyak 102 orang sebesar 56,7\% dan sisanya adalah responden berjenis kelamin pria sebanyak 78 orang sebesar 56,7\%. Sedangkan usia responden didominasi oleh mahasiswa berusia 21 - 25 tahun yaitu sebanyak 81 orang sebesar 45\%. Responden yang berusia $<20$ tahun sebanyak 54 orang sebesar 30\% sedangkan responden yang berusia 26 - 30 tahun sebanyak 36 orang sebesar 20\% kemudian responden yang berusia > 31 tahun sebanyak 9 orang atau hanya sebesar 5\%. Berdasarkan tempat studi mahasiswa, responden didominasi oleh mahasiswa yang melakukan studi pada Univ. Muhammadiyah Sidoarjo sebanyak 74 orang atau sebesar 41,1\% diikuti oleh responden yang 
melakukan studi pada Univ. Nahdlatul Ulama Sidoarjo sebanyak 48 orang atau sebesar 26,7\% selanjutnya responden yang melakukan studi pada STKIP PGRI Sidoarjo sebanyak 32 orang atau sebesar 17,8\% serta responden yang melakukan studi pada Akper Kerta Cendekia sebanyak 26 orang atau hanya sebesar 14,4\%.

\section{Hasil Pengujian Convergent Validity}

Evaluasi pertama pada model pengukuran adalah validitas konvergen (convergent validity). Untuk melihat hasil pengujian validitas konvergen, dilakukan dengan melihat hasil dari instrumen pengukuran (kuesioner) pada output combined loadings dan cross loading. Penilaiannya sendiri didasarkan pada kelayakan model apakah model tersebut valid dan memenuhi convergent validity. Selain itu kelayakan sebuah model juga dilihat dari nilai $\mathrm{t}$-statistiknya, dengan syarat $\mathrm{t}$-statistik harus lebih besar dari 1,96. Untuk selengkapnya, hasil pengujian validitas konvergen dari instrumen pengukuran pada penelitian dapat dilihat pada Tabel 2 di bawah ini.

Tabel 2

Hasil pengujian validitas konvergen

\begin{tabular}{lccc}
\hline & $\begin{array}{c}\text { Original } \\
\text { Sample }\end{array}$ & $\begin{array}{c}\text { Standard } \\
\text { Error }\end{array}$ & T Statistic \\
\hline VM1 <- Viral Marketing & 0,822 & 0,046 & 19,498 \\
VM2 <- Viral Marketing & 0,765 & 0,048 & 14,319 \\
VM3 <- Viral Marketing & 0,782 & 0,066 & 11,006 \\
KP1 <- Kepuasan Pelanggan & 0,821 & 0,047 & 16,599 \\
KP2 <- Kepuasan Pelanggan & 0,702 & 0,065 & 10,034 \\
KP3 <- Kepuasan Pelanggan & 0,842 & 0,036 & 26,302 \\
KP4 <- Kepuasan Pelanggan & 0,806 & 0,028 & 31,483 \\
KP5 <- Kepuasan Pelanggan & 0,767 & 0,055 & 12,642 \\
KB1 <- Keputusan Pembelian & 0,644 & 0,093 & 6,934 \\
KB2 <- Keputusan Pembelian & 0,770 & 0,044 & 16,821 \\
KB3 <- Keputusan Pembelian & 0,717 & 0,057 & 11,884 \\
KB4 <- Keputusan Pembelian & 0,651 & 0,063 & 9,783 \\
KB5 <- Keputusan Pembelian & 0,727 & 0,065 & 10,650 \\
\hline
\end{tabular}

Sumber: Data diolah 
Berdasarkan Tabel 2 disimpulkan bahwa seluruh indikator dari setiap variabel dinyatakan valid untuk mengukur variabelnya. Hal ini dapat dilihat dengan nilai output combined loadings dari semua indikatornya yang $>0,60$ dengan $\mathrm{t}$ - statistik $>1,96$.

\section{Hasil Pengujian Discriminant Validity}

Evaluasi kedua pada model pengukuran adalah validitas diskriminan (discriminant validity). Untuk mengukur validitas diskriminan dilakukan dengan menggunakan nilai cross loading. Suatu indikator dikatakan memenuhi discriminant validity jika nilai cross loading indikator terhadap variabelnya adalah yang terbesar dibandingkan terhadap variabel yang lainnya. Berikut adalah hasil uji Validitas Diskriminan dari masing - masing variabel :

Tabel 3

Hasil pengujian validitas diskriminan

\begin{tabular}{lccccc}
\hline & $\begin{array}{c}\text { Experiental } \\
\text { Marketing }\end{array}$ & $\begin{array}{c}\text { Viral } \\
\text { Marketing }\end{array}$ & $\begin{array}{c}\text { Kepuasan } \\
\text { Pelanggan }\end{array}$ & $\begin{array}{c}\text { Keputusan } \\
\text { Pembelian }\end{array}$ & Keterangan \\
\hline VM1 & 0,583 & $\mathbf{0 , 8 2 2}$ & 0,440 & 0,497 & Valid \\
VM2 & 0,540 & $\mathbf{0 , 7 6 5}$ & 0,381 & 0,467 & Valid \\
VM3 & 0,477 & $\mathbf{0 , 7 8 2}$ & 0,405 & 0,457 & Valid \\
KP1 & 0,561 & 0,531 & $\mathbf{0 , 8 2 1}$ & 0,501 & Valid \\
KP2 & 0,392 & 0,401 & $\mathbf{0 , 7 0 2}$ & 0,406 & Valid \\
KP3 & 0,456 & 0,376 & $\mathbf{0 , 8 4 2}$ & 0,509 & Valid \\
KP4 & 0,606 & 0,469 & $\mathbf{0 , 8 0 6}$ & 0,564 & Valid \\
KP5 & 0,396 & 0,215 & $\mathbf{0 , 7 6 7}$ & 0,436 & Valid \\
KB1 & 0,360 & 0,324 & 0,496 & $\mathbf{0 , 6 5 4}$ & Valid \\
KB2 & 0,520 & 0,476 & 0,596 & $\mathbf{0 , 7 7 0}$ & Valid \\
KB3 & 0,507 & 0,448 & 0,394 & $\mathbf{0 , 7 1 7}$ & Valid \\
KB4 & 0,427 & 0,407 & 0,267 & $\mathbf{0 , 6 5 1}$ & Valid \\
KB5 & 0,471 & 0,446 & 0,367 & $\mathbf{0 , 7 2 7}$ & Valid \\
\hline
\end{tabular}

Sumber: Data diolah

Berdasarkan nilai cross loading, dapat diketahui bahwa semua indikator yang menyusun masing - masing variabel dalam penelitian ini (nilai yang dicetak tebal) telah memenuhi discriminant validity karena memiliki nilai cross loading 
terbesar untuk variabel yang dibentuknya dan tidak pada variabel yang lain. Dengan demikian semua indikator di setiap variabel dalam penelitian ini telah memenuhi discriminant validity.

\section{Hasil Pengujian Composite Reliability}

Evaluasi terakhir pada outer model adalah composite reliability dan cronbach alpha. Composite reliability dan cronbach alpha digunakan untuk menguji nilai reliabilitas instrumen pada suatu variabel. Suatu variabel dikatakan memenuhi uji reliabilitas jika memiliki nilai composite reliability lebih besar dari 0,70 dan nilai cronbach alpha lebih besar dari 0,60. Berikut adalah nilai composite reliability dan cronbach alpha masing - masing variabel :

Tabel 4

Composite Reliability dan Cronbach Alpha

\begin{tabular}{lcc}
\hline & Composite Reliability & Cronbach Alpha \\
\hline Viral Marketing & 0,833 & 0,699 \\
Kepuasan Pelanggan & 0,892 & 0,849 \\
Keputusan Pembelian & 0,830 & 0,746 \\
\hline
\end{tabular}

Sumber: Data diolah

Dari tabel 4 menunjukkan bahwa nilai composite reliability semua variabel penelitian ini mempunyai nilai $>0,70$ dan nilai cronbach alpha $>0,60$ dengan demikian dapat dikatakan bahwa variabel Viral Marketing, Kepuasan Pelanggan dan Keputusan Pembelian memiliki tingkat reliabilitas yang tinggi.

\section{Hasil pengujian hipotesis}

Hasil pengujian hipotesis setiap variabel dengan menggunakan software SmartPLS dapat dilihat dalam tabel berikut:

Tabel 5

Path Coefficients

\begin{tabular}{lccc}
\hline & Original & Standard & \multirow{2}{*}{ T Statistics } \\
& Sample & Error & T \\
\hline Viral Marketing >> Kepuasan Pelanggan & 0,075 & 0,142 & 2,525 \\
\hline Viral Marketing >> Keputusan Pembelian & 0,291 & 0,110 & 2,639 \\
\hline
\end{tabular}


Keputusan Pembelian $>>$ Kepuasan Pelanggan

0,348

0,105

3,293

Sumber: Data diolah

Dari tabel tersebut dapat dijelaskan hasil analisis sebagai berikut:

1. Pengaruh Viral Marketing terhadap Kepuasan Pelanggan

Dengan melihat hasil Tabel 5 diketahui bahwa nilai koefisien path pada variabel Viral Marketing terhadap Kepuasan Pelanggan sebesar 0,075 dengan nilai T-Statistik sebesar 2,525. Karena nilai T-Statistik < 1,96 maka dapat diartikan bahwa Viral Marketing berpengaruh signifikan terhadap Kepuasan Pelanggan.

2. Pengaruh Viral Marketing terhadap Keputusan Pembelian

Dengan melihat hasil Tabel 5 diketahui bahwa nilai koefisien path pada variabel Viral Marketing terhadap Keputusan Pembelian sebesar 0,291 dengan nilai $\mathrm{T}$-Statistik sebesar 2,639. Karena nilai $\mathrm{T}$-Statistik $>1,96$ maka diartikan bahwa Viral Marketing berpengaruh signifikan terhadap Keputusan Pembelian.

3. Pengaruh Keputusan Pembelian terhadap Kepuasan Pelanggan

Dengan melihat hasil Tabel 5 diketahui bahwa nilai koefisien path pada variabel Keputusan Pembelian terhadap Kepuasan Pelanggan sebesar 0,348 dengan nilai $\mathrm{T}$-Statistik sebesar 3,293. Karena nilai $\mathrm{T}$-Statistik $>$ 1,96 maka dapat diartikan bahwa Keputusan Pembelian berpengaruh signifikan secara positis terhadap Kepuasan Pelanggan.

\section{Pembahasan}

Berikut akan dibahas temuan penelitian atas analisis data empiris sehubungan dengan hipotesis yang diajukan, yaitu :

1. Pengaruh Viral Marketing terhadap Kepuasan Pelanggan

Berdasarkan hasil analisis dapat dijelaskan bahwa viral marketing berpengaruh positif signifikan terhadap kepuasan pelanggan hal ini diartikan bahwa Viral Marketing dapat mengakibatkan terjadinya komunikasi yang terjadi antar konsumen, antar pemilik aplikasi Blackberry Messanger. Maka dari itu, di dunia maya pelaku atau pemilik akun yang melakukan Viral Marketing disebut dengan buzzer. Viral Marketing yang bekerja seperti penyebaran virus dalam 
dunia komunikasi pemasaran ditujukan agar pesan iklan yang dilempar ke masyarakat dapat disebarluaskan kembali berkali - kali ke orang lain. Tujuan Viral Marketing yang demikian dapat dilihat keberhasilannya melalui layanan yang disediakan Blackberry Messenger berupa Broadcast Message.

Hal ini sejalan dengan penelitian yang dilakukkan oleh Andini, Suharyono \& Sunarti ( 2014) menjelaskaan bahwa viral marketing berpengaruh terhadap kepercayaan pelanggan dan keputusan pembelian dimana diartikan bahwa strategi pemasaran viral marketing, yang nantinya perusahaan harus bisa membuat seorang konsumen dapat percaya dengan produk yang ditawarkan dan konsumen melakukan keputusan pembelian terhadap produk-produknya serta konsumen dapat merekomendasikan produk tersebut kepada konsumen lainnya. Membuat pelanggan menaruh kepercayaan dan membuat pelanggan melakukan keputusan pembelian terhadap produk yang ditawarkan tidaklah mudah apalagi produk yang dipasarkan.

2. Pengaruh Viral Marketing Terhadap Keputuasan Pembelian

Berdasarkan hasil analisis dapat dijelaskan bahwa viral marketing berpengaruh positif signifikan terhadap keputusan pembelian dimana dapat diartikan viral marketing yang dilakukkan oleh para pengguna blackberry smartphone sangat dipengaruhi oleh kecanggihan elektronik yang meny penyebaran pesan menjadi saluran untuk mengkomunikasikan suatu produk kepada para konsumen secara luas dan berkembang. Strategi ini dilakukan dengan harapan setiap konsumen yang mendapatkan informasi ini untuk disebarluasakan agar dapat mempengaruhi konsumen yang lain untuk melakukkan keputusan pembelian oleh karena itu viral marketing sangat dibutuhkan dalam pemasaran karena bersifat pemasaran dari mulut kemulut. Penelitian ini sejalan dengan penelitian yang dilakukkan oleh Wiludjeng dan Nurlela (2013) menjelasaka bahwa viral marketing berpengaruh secara signifikan pada keputusan beli konsumen sehingga produsen disarankan untuk melaksanakan viral marketing untuk ditingkatkan, mengingat pelaksanaan viral marketing dapat memberikan informasi lebih luas, cepat dan tepat kepada masyarakat.

3. Pengaruh Keputusan Pembelian terhadap Kepuasan Pelanggan

Berdasarkan hasil analisis dapat dijelaskan bahwa keputusan pembelian 
berpengaruh positif signifikan terhadap kepuasan pelanggan. Hal ini apat diartikan bahwa keputusan pembelian yang telah dilakukan oleh konsumen dalam hal ini mahasiswa pengguna aplikasi $B B M$ yang apabila setelah dia merasakan kenyamanan dan keamanan dalam hubungannya dengan penjual dan apa yang dia dapatkan sama dengan harapan yang diinginkan maka kepuasan yang dirasakan akan muncul.

\section{Kesimpulan}

Berdasarkan hasil pembahasan maka didapatkan beberapa kesimpulan sebagai berikut :

1. Viral Marketing berpengaruh positif signifikan terhadap Kepuasan Pelanggan, artinya dengan dilaksanakan aktivitas Viral Marketing yang baik dan menarik oleh pemasar dalam penggunaan aplikasi BlackBerry Messenger akan berdampak langsung terhadap Kepuasan Pelanggan pengguna Aplikasi BlackBerry Messenger tersebut.

2. Viral Marketing berpengaruh positif signifikan terhadap Keputusan Pembelian, artinya dengan dilaksanakannya Viral Marketing yang baik oleh pemasar dalam penggunaan aplikasi BlackBerry Messenger akan berdampak langsung terhadap Keputusan Pembelian pengguna Aplikasi BlackBerry Messenger tersebut.

3. Keputusan Pembelian berpengaruh positif signifikan terhadap Kepuasan Pelanggan, artinya dengan telah dilakukannya Keputusan Pembelian oleh pelanggan dalam penggunaan aplikasi BlackBerry Messenger akan berdampak langsung terhadap Kepuasan Pelanggan pengguna Aplikasi BlackBerry Messenger tersebut.

\section{Saran}

Berdasarkan hasil analisis penelitian yang telah dilakukan, selanjutnya disampaikan saran sebagai berikut:

1. Dalam hal mempromosikan produk baik berupa barang maupun jasa diharapkan untuk dapat menjaga kualitas promosi baik berupa kejujuran dalam kesesuaian produk yang ditawarkan maupun dari tingkat pelayanan yang diberikan kepada setiap calon pelanggan. Pemasar juga diharapkan melakukan kegiatan promosi tidak hanya dengan salah satu metode atau salah satu cara 
misalnya selain dengan menggunakan aplikasi BlackBerry Messenger pemasar juga dihimbau untuk melakukan promosi menggunakan cara mudah dan murah lainnya seperti menggunakan aplikasi Facebook ataupun Instagram.

2. Dalam hal menentukan keputusan untuk membeli diharapkan pada para pelanggan atau calon pelanggan untuk selalu lebih dahulu mencari informasi mengenai produk yang akan dibeli, baik secara langsung kepada pemasar ataupun dengan mencari pembanding lainnya. Pembeli atau calon pembeli disarankan untuk tetap berhati-hati dalam melakukan transaksi apalagi jika transaksi tersebut dilakukan secara online karena hal tersebut sangatlah rentan dengan penipuan. Pelanggan atau calon pelanggan dihimbau untuk lebih memilih melakukan transaksi dengan pemasar yang telah dikenal atau yang telah dipercaya sebelumnya.

3. Dalam penelitian selanjutnya diharapkan untuk dapat dikembangkan dengan mengidentifikasi variabel lain yang mempengaruhi Kepuasan Pelanggan dan Keputusan Pembelian seperti Experiential Marketing, Kualitas Pelayanan dan berbagai variabel lainnya. Selain itu penambahan jumlah sampel juga perlu diperhitungkan mengingat semakin bertambahnya jumlah mahasiswa yang dijadikan sampel dalam penelitian ini. Penelitian selanjutnya juga dapat mempertimbangkan metode lain dalam meneliti Kepuasan Pelanggan, misalnya melalui wawancara mendalam terhadap responden sehingga informasi yang diperoleh dapat lebih bervariasi daripada hanya menggunakan instrumen penelitian kuesioner dimana jawabannya sudah tersedia.

\section{Daftar Pustaka}

Andhini, Natasya Putri, Suharyono dan Sunarti. (2014). Pengaruh Viral Marketing terhadap Kepercayaan Pelanggan dan Keputusan Pembelian, Studi Pada Mahasiswa Fakultas Ilmu Administrasi Universitas Brawijaya Angkatan 2013 yang Melakukan Pembelian Online Melalui Media Sosial Instagram. Jurnal Administrasi Bisnis. Vol.11 No.1.

Fransiska, Indah. (2015). The Influence of Experiential Marketing to Customer Satisfaction, Case Study Against Mujigae Resto Festival Citylink Bandung. Tesis Universitas Telkom Bandung Tidak Diterbitkan .

Haryanto, Agus Tri. Rajai 109 Negara, WhatsApp Takluk dari BBM di Indonesia. https://inet.detik.com/cyberlife/d-3439085/rajai-109-negara-whatsapp-takluk- 
dari-bbm-di-indonesia. Diakses tanggal 9 September 2017.

Kotler, Philip dan Keller. (2009). Manajemen Pemasaran. Jilid I. Edisi ke 13. Jakarta: Erlangga.

Kotler, Philip. (2015). Marketing Management, 15 th Edition. New Jersey: Prentice Hall Inc. Kusumawati, Andriani. (2011). Analyzing the Influence of Experiential Marketing Customer Satisfaction and Loyalty: The case of Hypermart Malang Town Square. Jurnal Manajemen Pemasaran Modern, 3(1), pp 75-81.

Paragian, Yasser. Laporan: Mayoritas masyarakat Indonesia akses internet lewat perangkat. www.id.techinasia.com. Diakses pada tanggal 10 September 2017.

Priyandana, Andika. BBM, Tetap Nomor 1 di Indonesia! https://gintong.me/2017/09/09/bbm-tetap-nomor-1-di-indonesia. Diakses pada tanggal 9 September 2017.

Tejasukmana, V. A., dan S. Sugiharto. (2014). Analisis Pengaruh Experiential Marketing Terhadap Pembelian Ulang Konsumen The Vinnette (House of Bovin and Lynette) Surabaya. Jurnal Manajemen Pemasaran Petra Vol. 2 No. 1 Hal. 1-14, 2014.

Wahyuningtyas , Fatmawati Martha, Fauzi Achmad dan Arifin Zainul. (2017). The effect of experiential marketing on satisfaction and its impact on customer loyalty. Russian Journal of Agricultural and Socio-Economic Sciences (RJOAS), 1(61), January 2017. Pp 105-111.

Wardani, Atina Arlia. (2011). Analisis Pengaruh Experiential Marketing terhadap Keputusan Pembelian. Tesis Universitas Diponegoro Semarang Tidak Diterbitkan.

Wiludjeng, Sri dan Tresna Siti Nurlela. (2013). Pengaruh Viral Marketing terhadap Keputusan Pembelian pada PT. X. Proceeding Seminar Nasional dan Call for Papers SANCALL 2013. Surakarta, 23 maret 2013. ISBN: 978-979-636-147-2 